\title{
Visual Status and Causes of Low Vision and Blindness among HIV/AIDS Patients in Yenagoa, Bayelsa State, Nigeria
}

Azonobi I Richard* and Tebepah T

Department of Ophthalmology, Niger Delta University, Amassoma, Nigeria

\begin{abstract}
Background of study: The visual status and causes of visual impairment among HIVIAIDS patients in Yenagoa is not yet determined. In order to optimize the gain of an effective HIVIAIDS control programme, this information is vital.

Aim/Objectives: To determine the visual status and causes of visual impairment among HIV/AIDS patients in Yenagoa, Bayelsa state, Nigeria.

Method: A prospective cross sectional study was carried out on new consecutive HIV positive patients presenting to the "heart to heart" clinic of the Niger Delta University Teaching Hospital, Okolobiri over a period of 16 months. Relevant history was obtained from the patients and their base line data such as age, sex and CD4 count was recorded. The patients underwent a full ophthalmic examination including visual acuity assessment and an anterior and a posterior segment examination.

Result: One hundred and thirty nine patients (139), was evaluated consisting of 91 males and 48 females (M/F ratio of $1: 1.9)$. $15(10.8 \%)$ had visual impairment while $124(89.2 \%)$ had normal vision. Eighty (80 \%) of patients with visual impairment was found to be blind while $20 \%$ had low vision. Eighty percent $(80 \%)$ of patients with visual impairment has CD4 counts of 300 cells/ $\mu$ l or less. Retrobulbar optic neuritis was the commonest cause of blindness $(33.4 \%)$ followed by cataract $(24.9 \%)$ and maculopathy $(16.7 \%)$. Cytomegalovirus retinitis, herpes zoster ophthalmicus and toxoplasmosis were each responsible for $8.3 \%$ of blindness.

Conclusion: The visual status of this population was generally good. For a few with visual impairment, it was largely due to retrobulbar optic neuritis and cataract. Improvement of the visual status of this population must pay priority attention to these diseases.
\end{abstract}

Keyword: Blindness; Visual status; HIV/AIDS

\section{Introduction}

In 1981, the first case of HIV/AIDS infection was reported in the United States of America (USA) [1]. Since then the pandemic had taken a toll on the human race with diverse social and economic consequences and above all a potential for visual loss and ultimately blindness.

In north America and Europe, prior to the introduction of highly active antiretroviral therapy (HAART), it was found that $50-75 \%$ of HIV infected individuals develop non-refractive visual problems at some point during the course of the illness [2]. In the developing world, $5-25 \%$ of all HIV positive patients are expected to develop blindness at some point in time during the course of their illness [3]. Undoubtedly, patients with HIV/AIDS especially those in developing countries with poor standard of care are at risk of blindness or low vision. In the pre - HAART era, CMV retinitis was the commonest cause of visual loss in patients with HIV/AIDS infection and was responsible for $1-2$ million cases of bilateral vision loss worldwide [4]. However, with the widespread introduction of HAART and its attendant positive effect on immune recovery and eventual prognostic outlook on HIV/AIDS infection, other causes of visual loss are increasingly becoming apparent. Macular ischaemia has been found to be responsible for some cases of visual loss in HIV/AIDS infection [5-7]. Ischaemic maculopathy has been found to develop as a severe form of HIV microvasculopathy or as a complication of CMV retinitis [8,9]. A study has found cataract to be responsible for a significant proportion $(25 \%)$ of vision loss in HIV/AIDS patients [10]. Other causes of reduced vision in patients with HIV/AIDS infection include Herpes Zoster Ophthalmicus, Herpes simplex retinitis, Optic nerve disease, uveitis, refractive errors, glaucoma and diabetic retinopathaly $[3,11]$.
As part of the holistic intervention to the HIV/AIDS pandemic, visual preservation should be accorded a priority in order to optimize the gains of these interventions. In order to achieve this goal of visual preservation, it is necessary to know the visual status of these patients and the cause(s) of visual loss when it does occur. This information is largely unavailable in Bayelsa State, Nigeria. This study was therefore undertaken to provide this essential knowledge needed for the optimal care of HIV/AIDS patients in this population.

\section{Materials and Methods}

\section{Duration and place of study}

The study took place over a period of 16 months at the eye clinic of the Niger Delta University Teaching Hospital, Okolobiri, Bayelsa State.

\section{Method}

A descriptive prospective cross sectional study was carried out on every consecutive new HIV positive patient receiving treatment (HAART) at the Heart to Heart clinic of the Niger Delta University

*Corresponding author: Azonobi I Richard, Department of Ophthalmology, Niger Delta University, Amassoma, Nigeria, E-mail: doctorazonobi2002@ymail.com

Received February 14 , 2013; Accepted April 24, 2013; Published April 29, 2013

Citation: Richard Al, Tebepah T (2013) Visual Status and Causes of Low Vision and Blindness among HIVIAIDS Patients in Yenagoa, Bayelsa State, Nigeria. J AIDS Clin Res 4: 206. doi:10.4172/2155-6113.1000206

Copyright: @ 2013 Richard Al, et al. This is an open-access article distributed under the terms of the Creative Commons Attribution License, which permits unrestricted use, distribution, and reproduction in any medium, provided the original author and source are credited. 
Citation: Richard Al, Tebepah T (2013) Visual Status and Causes of Low Vision and Blindness among HIVIAIDS Patients in Yenagoa, Bayelsa State, Nigeria. J AIDS Clin Res 4: 206. doi:10.4172/2155-6113.1000206

Page 2 of 4

Teaching Hospital. Confirmed HIV patients referred from other units of the hospital were also included in this study. Relevant history was obtained from each patient and their baseline data such age, sex, and CD4 count was recorded. Each patient underwent full ophthalmic examination. Their visual acuties were determined at a distance of $6 \mathrm{~m}$ by a trained ophthalmic nurse with and without Pin hole using snellen acuity chart. Those that showed improvement with pin hole were refracted using a 534 Carl Zeiss auto-refractometer followed by a subjective refraction by an Optometrist. All patients had full ophthalmic examination. The anterior segment was examined using a pen torch and a slit lamp biomicroscope (Haag-strait) while the posterior segment was examined using direct and indirect ophthalmoscope (Keeler) as necessary by an Ophthalmologist(IR).Dilatation of the fund us where necessary was done using $1 \%$ tropicamide. All examination was done by one investigator (IR).

\section{Main outcome measures}

Blindness (Bilateral) was defined as a visual acuity of less than 3/60 in the better eye, while unilateral blindness was defined as a visual acuity of less than $3 / 60$ in the affected eye.

Low vision (Bilateral) was defined as a visual acuity of less than $6 / 18$ but equal to or greater than $3 / 60$ in the better eye while unilateral low vision was defined as a visual acuity of less than $6 / 18$ but equal to or greater than $3 / 60$ in the affected eye.

\section{Statistical analysis}

The data was collated and analysed using the statistical package of social scientist (SPSS) version 16 and a scientific calculator. They were presented as frequencies, percentages, means and standard deviation of means.

\section{Results}

During the period of this study, 139 previously diagnosed HIV patients were evaluated. They consisted of 91 females and 48 males (Male: Female ratio of 1:1.9). Their ages ranged from 9 to 66 years with a mean of 36.2 years $(S D \pm 10.0)$, (Table 1$)$.

Of this number, 124 (89.2\%) had normal vision, while 15 (10.8\%)

\begin{tabular}{|c|c|c|c|}
\hline \multirow{2}{*}{ Age(years) } & \multicolumn{2}{|c|}{$\operatorname{Sex}(\mathbf{n})$} & \multirow{2}{*}{ Total (n \%) } \\
\cline { 2 - 4 } & Male & Female & $2(1.4)$ \\
\hline $0-10$ & $2(1.44)$ & - & $2(1.4)$ \\
\hline $11-20$ & - & $2(1.44)$ & $34(24.46)$ \\
\hline $21-30$ & $4(2.88)$ & $30(21.58)$ & $59(42.45)$ \\
\hline $31-40$ & $19(13.66)$ & $40(28.8)$ & $27(19.4)$ \\
\hline $41-50$ & $13(9.35)$ & $14(10.07)$ & $11(7.9)$ \\
\hline $51-60$ & $6(4.31)$ & $5(3.6)$ & $4(2.9)$ \\
\hline $61-70$ & $4(2.88)$ & - & - \\
\hline$>70$ & - & - & $139(100.0)$ \\
\hline Total & $48(34.52)$ & $91(65.49)$ & \\
\hline & & & \\
\hline
\end{tabular}

Table 1: Age and sex distribution of study population.

\begin{tabular}{|c|c|c|c|}
\hline Visual Status & \multicolumn{2}{|c|}{ Type of impairment $(\mathrm{n} \%)$} & Total $(\mathrm{n} \%)$ \\
\hline & Bilateral & Unilateral & \\
\hline Blindness & $2(12.3)$ & $10(66.7)$ & $12(79.9)$ \\
\hline Low Vision & $1(6.7)$ & $2(13.3)$ & $3(20.0)$ \\
\hline Total & $3(20.0)$ & $12(79.9)$ & $15(100.0)$ \\
\hline
\end{tabular}

Table 2: Visual Impairment in the Study Population.

\begin{tabular}{|c|c|c|}
\hline Category / Causes of Blindness & Number & Percent \\
\hline (A)Bilateral blindness & & \\
\hline Retrobulbur optic neuropathy & 2 & 16.7 \\
\hline (B)Unilateral blindness & & \\
\hline Cataract & 3 & 24.9 \\
\hline Retrobulbar optic neuropathy & 2 & 16.7 \\
\hline Maculopathy & 2 & 16.7 \\
\hline Cytomegalovirus retinitis & 1 & 8.3 \\
\hline Herpes zoster ophthalmicus & 1 & 8.3 \\
\hline Toxoplasmosis & 1 & 8.3 \\
\hline Total & 12 & 100.0 \\
\hline
\end{tabular}

Table 3: Causes of Blindness in the Study Population.

\begin{tabular}{|c|c|c|}
\hline Category / Causes of low vision & Number & Percent \\
\hline (A)Bilateral low vision & & \\
\hline Glaucoma & 1 & 33.3 \\
\hline (B)Unilateral low vision & & \\
\hline Uveitis & 2 & 66.6 \\
\hline Total & 3 & 100.0 \\
\hline
\end{tabular}

Table 4: Causes of low vision in the Study Population.

had visual impairment. Among patients with visual impairment, 12 (79.7\%) were blind in one or both eyes (2 bilateral blindness (13.3\%), 10 unilateral blindness (66.7\%), while 3 had low vision (20.0\%), (Table 2).

Retrobulbar optic neuritis was responsible for 2 cases each of bilateral and unilateral blindness respectively, constituting 33.4\% of total blindness, (Table 3).

Cataract was the commonest cause of unilateral blindness and second commonest cause of overall blindness (24.9\%), followed by Maculopathy (16.7\%). Cytomegalovirus retinitis, Herpes zoster Ophthalmicus and Toxoplasmosis were each responsible for $8.3 \%$ of overall blindness in this population.

The cause of low vision in the study population is shown in Table 4. Uveitis was the commonest cause of low vision (66.3\%), followed by Glaucoma (33.3\%).

Eighty percent of patients with visual impairment have CD4 counts ranging from 0 to 300 cells/ $\mu \mathrm{l}$,Table 5 .

Patients with normal vision had an average CD4 count of 352.9 (SD \pm 249.8 ) while those with visual impairment had an average CD4 count of $186.7(\mathrm{SD} \pm 163.3)$.

\section{Discussion}

The prevalence of visual impairment among HIV/AIDS patients in this study was found to be $10.8 \%$. This is consistent with $11 \%$ found by Otiti-Sengeri among HIV patients in Uganda [12] and at variance with $20 \%$ and $27 \%$ respectively recorded by Pathai et al. [13] and Shah et al. [14], both in India. It has been found that the lower the CD4 count, the more likelihood of a patient suffering from visual impairment compared to a higher CD4 count level $[12,14]$. This is consistent with our finding as majorities (80\%) of patients with visual impairment have CD4 count of 300 cells $/ \mu \mathrm{l}$ or less. The average CD4 count in our study was 269.8 cells/ $\mu \mathrm{l}$ while those for the studies by pathai et al. [13] and shah et al. [14] was $180 \mathrm{cells} / \mu \mathrm{l}$ and $200 \mathrm{cell} / \mu \mathrm{l}$ respectively. The higher average level of CD4 count in our study compared to previous authors may be responsible for the lower prevalence of visual impairment recorded. The prevalence of blindness (bilateral and unilateral combined) in this population was found to be $8.6 \%$ while that of low vision (bilateral and 
Citation: Richard Al, Tebepah T (2013) Visual Status and Causes of Low Vision and Blindness among HIV/AIDS Patients in Yenagoa, Bayelsa State, Nigeria. J AIDS Clin Res 4: 206. doi:10.4172/2155-6113.1000206

\begin{tabular}{|c|c|c|}
\hline CD4 count & \multicolumn{2}{|c|}{ Visual impairment } \\
\hline & Number & Percent \\
\hline $0-50$ & 2 & 13.3 \\
\hline $51-100$ & 4 & 26.6 \\
\hline $101-150$ & 2 & 13.3 \\
\hline $151-200$ & 1 & 6.7 \\
\hline $201-250$ & 1 & 6.7 \\
\hline $251-300$ & 2 & 13.3 \\
\hline $301-350$ & - & - \\
\hline $351-400$ & 1 & 6.7 \\
\hline $401-450$ & 1 & 6.7 \\
\hline $451-500$ & - & - \\
\hline $501-550$ & 1 & 6.7 \\
\hline$>500$ & 1 & 6.7 \\
\hline Total & 15 & 100 \\
\hline \multicolumn{2}{|c|}{ Table 5: Visual impairment according to CD4 count. } \\
\hline
\end{tabular}

unilateral) was found to be $2.2 \%$. This is similar with $4.7 \%$ and $2.2 \%$ respectively recorded (extrapolation) by Otiti-Sengeri in Uganda [12].

However, the above contrasts with the findings of shah et al. in India [14], where the prevalence of blindness and low vision was found to be $1.0 \%$ and $6.2 \%$ respectively. The patients involved in these studies were at various stages of treatment with highly active antiretroviral therapy (HAART). HAART is known to have a positive effect on immune recovery and ocular complications [15]. This observation coupled with the fact that their compliance to treatment is likely to vary, may explain the differences in prevalence recorded by various researchers.

Retrobulbur optic neuritis as a cause of blindness or visual loss in HIV/AIDS patients has been emphasized [16,17]. Retrobulbar optic neuritis was the commonest cause of blindness in our study population accounting for $33.4 \%$ of cases. This is similar with the findings in Uganda where optic neuropathy was the commonest cause of blindness and responsible for $30 \%$ of cases [12]. However, unlike the findings in Uganda, no case of optic atrophy or papilloedema was found in our series.

Cataract was the second commonest cause of blindness in this study and was responsible for $24.9 \%$ of blindness. Otiti-Sengeri [12] in Uganda found cataract to be responsible for $17.5 \%$ of blindness in their study. Unlike the situation in Africa where the use of HAART is still not widespread, cataract has been found to be a common cause of visual loss in North America in the HAART era [18]. Cataract is said to occur as a complication of intraocular inflammation due to immune recovery uveitis in patients with CMV retinitis [19]. It has also been found to occur as a consequence of inflammation in necrotizing retinitis as in progressive outer retina necrosis [20] and acute retinitis [21]. It can also occur in association with long term use of nucleoside analogue reverse transcriptase inhibitors [22]. One out of the cataracts in this study was caused by trauma. The cause of the other 2 cases of cataract was not known. The patients in this study have been on HAART ranging from a period of less than 1 month to five years. Consequently, the possibility of the cataracts resulting from the long term use of HAART cannot be ruled out completely. Further studies are suggested to resolve this, considering the age of the patients (43 and 53years).

Maculopathy in recent times has been reported as a common cause of visual loss in patients with HIV/AIDS [6,7]. In our study, maculopathy was the third commonest cause of blindness and was responsible for $16.7 \%$ of cases. Maculopathy in HIV/AIDS patients may be due to the direct effect of HIV on the microvasculature of the retina or as a consequence of associated infections in HIV [23]. These microvascular changes including alteration in blood flow leads to ischaemia of the macular and consequent visual loss as evidenced by fluorescein angiography $[24,25]$. Herpetic and cytomegalovirus infections has been found to be common causes of maculopathy in patients with HIV/AIDS infection $[23,25]$. The causes of maculopathy in this study are not known because of absence of good laboratory back up.

Cytomegalovirus retinitis is a rare cause of blindness in this population and was responsible for $8.3 \%$ of blindness. In Uganda [12], it was responsible for $17.8 \%$ of blindness. In the pre-HAART era, cytomegalovirus retinitis was the commonest cause of visual loss among HIV/AIDS patients [2,26]. However, with the widespread availability of HAART, visual loss and blindness due to CMV retinitis has substantially reduced [18].The patients involved in this study were on HAART from a period ranging from less than one month to 5years. The low incidence of blindness due to CMV retinitis in this study may be due to the effect of HAART.

Although rare, Herpes Zoster Ophthalmicus is a cause of visual loss in patients with HIV/AIDS $[3,27,28]$. In this study, it was responsible for $8.3 \%$ of blindness. This is similar to the findings in Uganda [12] (3.5\%). Herpes Zoster virus is known to cause keratitis, uveitis, retinitis, optic neuritis and central retinal vein occlusion in HIV/AIDS infected patients leading to visual impairment [29-31]. Keratitis was the cause of visual impairment in our study. HIV/AIDS patients presenting with Herpes Zoster ophthalmicus must be thoroughly examined for early detection and treatment of these complications.

Ocular Toxoplasmosis was responsible for $8.3 \%$ of blindness among HIV infected patients in this study. It was responsible for $15.8 \%$ of blindness among HIV patients in Uganda [12]. Toxoplasmosis is an opportunistic infection in patients with HIV infection [32]. With widespread availability of HAART, its incidence and impact on vision is likely to diminish. The patients in our study were at different stages of treatment with HAART. The lower incidence of blindness due to toxoplasmosis compared with previous study may be due to the effect of HAART.

\section{Limitation of Study}

The number of patients with visual impairment in this study is low. To conclusively determine the causes of visual impairment in this population a larger population need to be examined in order to increase the yield of cases of visual impairment. However our finding gives an idea of the true situation.

\section{Conclusion}

Majority of HIV infected persons in this population have normal visual status (89.2\%). However, for the minority with visual impairment (10.8\%), retrobulbur optic neuropathy was the commonest cause of blindness (33.4\%) followed by cataract (24.9\%) and maculopathy (16.7\%). As these complications may mar the beauty of a successfully implemented HAART programme due to their visual effect, early identification and treatment of these complications may improve the overall quality of life of these patients.

\section{References}

1. Centers for Disease Control (CDC) (1981) Pneumocystis pneumonia--Los Angeles. MMWR Morb Mortal Wkly Rep 30: 250-252.

2. Holbrook JT, Jabs DA, Weinberg DV, Lewis RA, Davis MD, et al. (2003) Visual loss in patients with cytomegalovirus retinitis and acquired immunodeficiency 
Citation: Richard Al, Tebepah T (2013) Visual Status and Causes of Low Vision and Blindness among HIV/AIDS Patients in Yenagoa, Bayelsa State, Nigeria. J AIDS Clin Res 4: 206. doi:10.4172/2155-6113.1000206

syndrome before widespread availability of highly active antiretroviral therapy. Arch Ophthalmol 121: 99-107.

3. Kestelyn PG, Cunningham ET Jr (2001) HIV/AIDS and blindness. Bull World Health Organ 79: 208-213.

4. Cunningham ET Jr, Lietman TM, Whitcher JP (2001) Blindness: a global priority for the twenty-first century. Bull World Health Organ 79: 180.

5. Vitale AT (2005) Global HIVIAIDS and visual impairment. Cataract and refractive surgery today.

6. Akduman L, Feiner MA, Olk RJ, Kaplan HJ (1997) Macular ischemia as a cause of decreased vision in a patient with acquired immunodeficiency syndrome. Am J Ophthalmol 124: 699-702.

7. Romano MR, Valldeperas X, Romano F (2006) Bilateral ischemic maculopathy in a patient with AIDS. Eur J Ophthalmol 16: 761-763

8. Vrabec TR (2004) Posterior segment manifestations of HIVIAIDS. Surv Ophthalmol 49: 131-157.

9. Raina J, Bainbridge JW, Shah SM (2000) Decreased visual acuity in patients with cytomegalovirus retinitis and AIDS. Eye (Lond) $14: 8-12$

10. Thorne JE, Holbrook JT, Jabs DA, Kempen JH, Nichols C, et al. (2007) Effect of cytomegalovirus retinitis on the risk of visual acuity loss among patients with AIDS. Ophthalmology 114: 591-598.

11. Goyal JL, De Sarmi, Singh NP, Bhatia A (2003) Evaluation of visual functions in patients on ethambutol therapy for tuberculosis: a prospective study. J Commun Dis 35: 230-243.

12. Otiti-Sengeri J, Colebunders R, Kempen JH, Ronald A, Sande M, et al. (2010) The prevalence and causes of visual loss among HIV-infected individuals in Uganda. J Acquir Immune Defic Syndr 53: 95-101.

13. Pathai S, Deshpande A, Gilbert C, Lawn SD (2009) Prevalence of HIVassociated ophthalmic disease among patients enrolling for antiretroviral treatment in India: a cross-sectional study. BMC Infect Dis 9: 158.

14. Shah SU, Kerkar SP, Pazare AR (2009) Evaluation of ocular manifestations and blindness in HIVIAIDS patients on HAART in a tertiary care hospital in western India. Br J Ophthalmol 93: 88-90.

15. Autran B, Carcelain G, Li TS, Blanc C, Mathez D, et al. (1997) Positive effects of combined antiretroviral therapy on CD4+ T cell homeostasis and function in advanced HIV disease. Science 277: 112-116.

16. AlimanoviÄ-HaliloviÄ E, IbiseviÄ M (2007) Retrobulbar optic neuritis as first sign of HIV infection. Med Arh 61: 128-130.

17. Liu JZ, Brown P, Tselis A (2005) Unilateral retrobulbar optic neuritis due to varicella zoster virus in a patient with AIDS: a case report and review of the literature. J Neurol Sci 237: 97-101.
18. Thorne JE, Jabs DA, Kempen JH, Holbrook JT, Nichols C et al. (2006) Causes of visual acuity loss among patients with AIDS and cytomegalovirus retinitis in the era of highly active antiretroviral therapy. Ophthalmology 113: $1441-1445$

19. Kempen JH, Sugar EA, Lyon AT, Lewis RA, Jabs DA, et al. (2012) Risk of cataract in persons with cytomegalovirus retinitis and the acquired immune deficiency syndrome. Ophthalmology 119: 2343-2350.

20. Engstrom RE Jr, Holland GN, Margolis TP, Muccioli C, Lindley Jl, et al. (1994) The progressive outer retinal necrosis syndrome. A variant of necrotizing herpetic retinopathy in patients with AIDS. Ophthalmology 101: 1488-1502.

21. Blumenkranz MS, Culbertson WW, Clarkson JG, Dix R (1986) Treatment of the acute retinal necrosis syndrome with intravenous acyclovir. Ophthalmology 93: $296-300$

22. Gaynes BI (2005) "Star" suture opacities of the crystalline lens: an illustrative report in AIDS patients. Med Sci Monit 11: PI9-13.

23. Rocha lima B (2004) Ophthalmic manifestations of HIV infection. Digital Ophthalmology 10

24. Cunningham ET Jr, Levinson RD, Jampol LM, Engstrom RE Jr, Lewis $H$, et al. (2001) Ischemic maculopathy in patients with acquired immunodeficiency syndrome. Am J Ophthalmol 132: 727-733.

25. Correa ZM, Bellini LP, Falci D, Freitas AM, Marcon LM (2003) Ischaemic maculopathy in patients with acquired immunodeficiency syndrome and CD4 T-Lymphocyte count under 50 cells/ $\mu$ l. Invest Ophthalmol Vis Sci 44: 4614

26. Stewart MW (2011) Impact of HIV on vision. Northeast Florida Medicine 62: 3-8

27. Umeh RE (1998) Herpes zoster ophthalmicus and HIV infection in Nigeria. In J STD AIDS 9: 476-479.

28. Adio AO, Fiebai B (2010) Herpes zoster ophthalmicus and HIV seropositivity in South-south Nigeria. Niger J Med 19: 162-164

29. Looney BD (1997) Herpes Zoster Ophthalmicus. Clinical Eye and vision care 9: 203-211.

30. Greven CM, Singh T, Stanton CA, Martin TJ (2001) Optic chiasm, optic nerve and retinal involvement secondary to varicella-zoster virus. Arch Ophthalmo 119: $608-610$.

31. Biswas J, Deka S, Padmaja S, Madhavan HN, Kumarasamy N, et al. (2001) Central retinal vein occlusion due to herpes zoster as the initial presenting sign in a patient with acquired immunodeficiency syndrome (AIDS). Ocul Immuno Inflamm 9: 125-130.

32. Meisheri YV, Mehta S, Patel U (1997) A prospective study of seroprevalence of Toxoplasmosis in general population, and in HIVIAIDS patients in Bombay, India. J Postgrad Med 43: 93-97. 